\title{
ON THE ANATOMY OF PTEROCERA, WITH SOME NOTES ON THE CRYSTALLINE STYLE.
} By M. F. Woodward, Demonstrator of Zoology, Royal College of
Science, London.

Read May 11th, 1894.

\section{PLATE XI.}

IT might at first sight seem unnecessary to redescribe the anatomy of Pterocera, figures of which appear in all our leading text books; these, however, are all derived from one source, ${ }^{1}$ and that original is itself inaccurate in some important respects.

The specimen on which the present observations were made was kindly given me by Prof. Haddon, who collected it in Torres Straits ; it had been removed from the shell and earefully preserved in spirit; the absence of the shell, however, prevents me from determining the species.

Pterocera is a Prosobranchiate Gastropod belonging to the Tænioglossate division of the Pectinibranchiata and to the family Strombidæ. It closely resembles the allied genus Strombus, both in its shell and the peculiar form of the head, foot, and operculum.

Very good figures of the living animal are given by Quoy and Gaimard, ${ }^{1}$ and except for the fact that my specimen was a spirit one, and, consequently, the foot and head were somewhat contracted, there were no differences in the external characters. The enormous size of the optic stalks and the eyes is very noticeable in the Strombidæ, and their position in relation to the peristome is very marked; the left optic stalk occupies the anterior canal with the siphon, while the right one is lodged in that notch in the peristome so characteristic of this family.

The foot in these forms is long and narrow, and the creeping dise seems to be entirely wanting; it is divided into two well-marked portions - an anterior heel-shaped structure, rather contracted in my specimen, and a posterior pointed toe, bearing on its dorsal surface the long, pointed, nail-like operculum, which projects back freely from the foot.

These snails have entirely lost the creeping method of progression, and are said to get over the ground by a series of leaping movements. In the allied genus Aporrhais the foot is not quite so narrow, but even here the creeping habit has been lost, the animal progressing by digging its sharp operculum into the ground and then extending its foot, thus forcing the body and shell forwards; the foot

1 Voyage de l'Astrolabe. Zoologie par MM. Quoy and Gaimard, tom. iii. p. 878, pl. xlix. fig. 18. "Strombus lambis." 
is then retracted and the process repeated. In this manner the animal progresses slowly by a series of loop-like movements of extension and contraction, in which the sharp-pointed and freelyprojecting operculum plays a very important part. I am inclined to believe that progression in Pterocera is effected in a similar manner rather than by a leaping movement.

The mantle shows but slight indications of those characteristic processes which secrete the claw-like prolongations of the peristome, both these and the anterior siphon being evidently highly retractile.

On opening the mantle cavity the large grooved penis is seen doubled up within this chamber, the free end being flattened and expanded. ${ }^{1}$ The rectum forms a prominent ridge down the right side of the dorsal wall of the mantle chamber, and the anus is situated on the tip of a pointed freely projecting promontory close to the edge of the mantle. High up, near the upper part of the rectum, and close to the angle between the body and the mantle fold, is the swollen glandular termination of the vas deferens, opening by a small aperture, from which there extends a long open groove (possibly ciliated) down the mantle and body wall to the penis, along the entire length of which it runs.

The renal aperture, which, like the kidney itself, is large, is placed close to the posterior end of the gill and to the pericardium. Quoy and Gaimard, ${ }^{2}$ and Kieferstein ${ }^{3}$ both speak of the kidney as the uterus. The mucous gland is apparently subdivided into two portions, a large one near the rectum and a smaller one close to the gill. The gill is large and its efferent branchial vein runs along its left border.

The osphradium (parabranchia, nebenkieme,$^{3}$ petite branchie ${ }^{2}$ ) is present as a long granular line situated to the left of the gill and running down to the siphon; when examined under a lens it is seen to have the structure of a double comb.

The anterior portion of the body, which tapers off into the foot, forms the convex floor of the mantle cavity, and is compressed dorsoventrally. It consists almost entirely of a muscle-mass, which is attached to the shell dorsally by the columella muscle, the viscera occupying but a narrow tube in the middle of this mass.

The mouth opens on the end of the non-retractile muzzle, and is armed with a pair of laterally-placed gelatino-chitinous jaws : it communicates with a small buccal mass containing a well-developed odontophore and radula sac; from this proceeds a short and narrow osophagus, on which is placed a pair of slightly branched salivary glands opening into the buccal mass. These structures all lie within the muzzle. The œsophagus on entering the body becomes suddenly enlarged to form the crop; this structure, which is about $4 \frac{1}{2}$ inches long, tapers

1 Carus, Icones Zootomicæ, copies the figure of Quoy and Gaimard's female specimen, which he calls a male and letters the foot as the penis.

2 Voyage de l'Astrolabe. Zoologie par MM. Quoy and Gaimard, tom. iii. p. 878, pl. xlix. fig. 18 ; "Strombus lambis."

3 Bronn's Klassen u. Ordnung. d. Thier-Reichs. Bd. iii. Abth. 2. Malacozoa, 1862-66. Pl. lxxxiii. fig. 2, $u$. 
gradually away into a small tube, and is situated, together with the anterior aorta, in a narrow channel-like body-cavity hollowed out of the great anterior muscular mass of the body; from this it passes into the coiled visceral mass, and running through the liver becomes slightly funnel-shaped and enters the stomach.

The structure of the stomach was described by Huxley, ${ }^{1}$ but since my observations differ somewhat from his I append a short description of it. The stomach is a trilobed sac buried in the lower part of the liver and near the right side of the body; its dorsal border, which we may, for convenience, call the greater curvature, exhibits two well-marked constrictions; the osophagus enters the middle chamber on its ventral border or lesser curvature, to the left of which we find the posterior chamber as a small round cardiac sac. The intestine leaves the pyloric portion of the stomach as a very narrow tube, situated just anterior to the cardiac orifice; this pyloric sac is continued forward, and finally gives off a long cæcal tube which runs through the liver, over the anterior aorta, and, passing close to the left of the pericardium, enters the dorsal mantle wall, down which it extends just to the left of the osphradium, nearly the whole length of the gill, where it ends abruptly. This cæcum contains a body having all the structure and relation of the crystalline style of the Lamellibranchiata. The existence of this structure was first pointed out by Collier, ${ }^{2}$ and afterwards by Huxley, ${ }^{1}$ and I shall refer to this point later on.

On opening the stomach, it is seen that the two constrictions are still more marked internally than externally, owing to the development of a couple of sharp ridges of almost cartilaginous nature and tooth-like form; these thin out on either side on the walls of the sacculations, so that the stomach is almost completely lined by a firm transparent secretion of its lining epithelium, reminding one of the horny lining of a bird's gizzard, the tooth-like structures corresponding in function to the horny plates of that organ. These structures, which are to a large extent protective as well as crushing organs, correspond in every respect to the sagitta or "flêche tricuspide" of the Lamellibranchiata, and, like that tissue, are composed of a substance giving reactions very similar to those of mucin.

Opening into the cardiac sac we find the right bile duct, while the left one opens into the pyloric sac close to the origin of the cæcum. Within the latter structure is the well-developed crystalline style about 4 inches long, tapering away to a point at the blind end of the sac, while its free end, which is broad and flat, projects into the pylorus and abuts against the large anterior tooth-ridge. This free end is of a less homogeneous nature than the rest of the style, and assimilates the appearance of the recently digested food.

The stomach was full, and its contents show the animal to be a very mixed feeder, plant remains being abundant, especially threads of blue-green algæ and brown seaweeds; in addition there were a

1 Huxley, Phil. Trans. 1853, pp. 60-61.

2 Edinb. New Phil. Journ., vol. vii. 1829, pp. 230-231. 
quantity of sand-grains, sponge spicules, a few small Crustacea, and numerous large Foraminifera of the genus Orbiculina. Whether the animal swallows these as part of its diet or merely to assist it in triturating its vegetable and animal food I am unable to say, but one thing is certain, that they do not pass entire through the intestine, since the pyloric orifice is far too small. I am inclined to think that they serve both for nourishment and as triturators, and eventually even the calcareous shell may be absorbed, seeing that Pterocera must need a large amount of lime for the formation of its shell while growing. 'The intestine is very narrow; it curves round the anterior border of the liver and, passing under the kidney, becomes suddenly enlarged and passes into the rectum; this latter runs round the right border of the kidney and opens into the mantle chamber by a small anal orifice.

The heart is large and gives rise to a long anterior, and a shorter posterior, aorta.

The kidney is well developed : it is composed of two well-marked pectinate glandular masses and a large receptive cavity, opening externally into the mantle chamber and internally into the pericardium. This organ is the first part of the uterus of Quoy and Gaimard and Kieferstein.

The genital organs are simple, as in all Prosobranchs, a long testis occupying the dorsal border of the coiled visceral mass, from which spring several coiled tubes that unite to form a closely coiled vas deferens. This latter increases in size, its walls become glandular, and it finally enters a short straight tube with thick glandular walls, that opens at the upper end of the mantle cavity; from this aperture an open groove extends down into the penis.

The specimen figured by Carus as a male is really a female, being a bad copy of Quoy and Gaimard's figures with this new interpretation: he closes the opening of the oviduct and, covering in the pedal groove of their specimen, places the genital aperture in the anterior division of the foot. Quoy and Gaimard's figure of the female organs, with the exception of the confusion between the kidney and uterus, compares well with that given by Haller ${ }^{1}$ for Strombus, including the curiously branched uterus and the long ciliated groove leading from the genital orifice down to the foot, the function of which it is difficult to understand, unless it be concerned in oviposition.

The nervous system is that of a typical streptoneurous form, and consists of a nerve ring placed round the junction of the crop and œsophagus, on which there are well-marked cerebral ganglia, supplying the snout and eyes; behind these a pair of pleural ganglia, and below the œsophagus two pedal ganglia, the latter giving off numerous pedal nerves, while from the pleural arise a pair of visceral nerves, that springing from the right side, crosses over the crop, and ends in a splanchnic ganglion on the left side, whence the nerve of the osphradium originates, while the left nerve passes under the crop and supplies the

1 Haller, Morph. Jahr. Bd. xix. 1893, pl. xix. fig. 17. 
right splanchnic ganglion. A pair of otocysts are closely applied to the pedal ganglia, differing from those of Strombus in being situated behind instead of anterior to the pedal ganglia.

The Crystalline Style in its most typical condition is a firm, gelatinous, transparent rod, situated in a cæcal diverticulum of the stomach, into the cavity of which it projects freely. The style is generally regarded as being peculiar to the Lamellibranchiata, and amongst them to be restricted to the Dimyarian forms. This, however, is not the casé, as was shown as long ago as 1829 by Collier, ${ }^{1}$ who wrote as follows: "There is an organ, the crystalline stiletto, confined erroneously by a celebrated naturalist to bivalves, which is found in every species of Strombus, in Trochus turritus, and a species (vertagus) of Murex." He further gives a detailed description of the position and character of this structure. These observations were subsequently confirmed by Huxley in Pterocera. ${ }^{2}$

In 1855 Moquin-Tandon ${ }^{3}$ described in Bythinia a long cartilaginous rod, which he considered the analogue of the crystalline style of the Lamellibranchiata. Fischer ${ }^{4}$ speaks of a free chitinous (?) lamella shaped like the screw-propeller of a boat in the stomach of Cyclostoma (evidently the "flêche tricuspide"), and states that a stylet analogous to this is found in Paludina (? the same as in Bythinia), Trochus, and Strombus, but he evidently does not regard it as having any relation to the crystalline style of the Lamellibranchs. We also find its presence described by Von Jhering ${ }^{5}$ in Lythoglyphus. Haller ${ }^{6}$ has described the presence in Strombus and in Rostellaria of a long tapering cæcal outgrowth from the pyloric end of the stomach; this is obviously the homologue of the crystalline style sac of Pterocera. He does not, however, describe any solid style as being found within this cæcum, nor does he make any reference to Collier's or Huxley's description of Pterocera, or compare this cæcum with that of the Lamellibranchs. He figures a slight cæcal outgrowth in Dolium galea, and in speaking of the cæcum of Haliotis (see also Lang $^{7}$ ) suggests that it is concerned in storing up and absorbing the fluid food. Yung ${ }^{8}$ describes in Helix pomatia a cuticular lining to the intestine, which he compares with the crystalline style of Lamellibranchs. Kieferstein ${ }^{9}$ also describes a small pyloric cæcum in Murex and Buccinum.

We see from the above that the presence of a crystalline style in the Gastropoda, and its connection with the stomach or intestine (i.e. midgut), either in a distinct cæcum (Strombidæ) or free in the

1 Edinb. New Phill. Journ. viol. vii. 1829, pp. 230-231.

2 Huxley, Phil. Trans. 1853, p. 60.

3 Moquin-Tandon, Moll. Terr. et Fluv. France, 1855, tome i. p. 44.

4 Fischer, Manuel d. Conchyliologie, p. 41.

5 Von Jhering, Mal. Blätter (2), viii. p. 98.

${ }^{6}$ Haller, Morph. Jahr. Bd. xix. 1893, pp. 582-584.

7 Lang, Lehrb. Vergl. Anat. p. 774.

8 Yung, Mém. Cour. Acad. Belg. 4to. t. xlix. No. 1, p. 34.

9 Bronn's Klassen u. Ordnung. d. Thier.-Reichs. Bd. iii. Abth. 2, Malacozoa, $1862-66$. 
gut (Helix), was known long ago, yet several modern books dealing with Mollusca still regard it as peculiar to the Acephala, and one, published within the last twelve years, still retains the old exploded idea of Meckel and Garner that the cæcum is connected with the pharynx (foregut) and represents the radula sac of the odontophora, the style representing some part of the odontophore.

The belief that the crystalline style was peculiar to the Dimyarian Lamellibranchs has been long ago shown to be erroneous, this structure being now known to be present in several Monomyarian genera, as for instance Anomia, ${ }^{1}$ Ostrea, and Pecten; it is not however in all cases provided with a special cæcum, but lies freely in the lumen of the intestine: this may account for its presence having been overlooked for so long, in spite of its large size-for example in a specimen of $P$. maximus, whose shell had a maximum width of $4 \frac{3}{4}$ inches, there was present in the intestine a crystalline style $3 \frac{1}{4}$ inches long.

For full details of the relation of this structure as found in the Lamellibranchiata I would refer those interested to Barrois' ${ }^{2}$ very full and detailed account, which deals with the historical, anatomical, and physiological sides of the question.

With regard to the function of this style and the sagitta or "flêche tricuspide" Barrois comes to the following conclusions: he regards the latter as a protective coating to the stomach formed at the expense of the epithelium lining that organ, while the former he considers to be a product continuously secreted by the lining epithelium of the cæcum, and gradually moved forwards into the stomach by the action of the cilia, where it is dissolved by the secretion of the digestive glands, and acts as a lubricant, covering any sharp particles and enabling them to traverse the intestine without damaging it. He considers in great detail the recent views of $\mathrm{Hazay}^{3}$ and Haseloff ${ }^{4}$ that the style is a reserve supply of food material, but finds himself unable to support them, basing his arguments largely on physiological grounds; but he also tried Haseloff's starving experiments, using Cardium instead of Mytilus, and obtained no results-probably because he did not starve them long enough. $\mathrm{He}$ also contests the view of Milne-Edwards ${ }^{5}$ and others that the style and sagitta have any mastioatory function.

Respecting this last conclusion I think that, although the sagitta is in the main protective, it further serves, as does also the enlarged end of the crystalline style, which abuts against the former, as a triturating organ. I am especially led to this conclusion by the presence of the large Foraminifera in the stomaoh of Pterocera, that certainly are broken up before entering the narrow intestine, and also from the

1 Garner, Trans. Zool. Soc. ii. 1841, p. 89.

2 Barrois, Revue Biol. d. Nord., 1888-89, pp. 124, 161, 263 ; 1889-90, pp. 209, 299,351 .

${ }^{3}$ Hazay, D. Mollusken-Fauna v. Budapest, ii. Biologischen Thiel. pp. 159-165. Cassel, 1881.

4 Haseloff, W. d Krystallstiel d. Muscheln. Osterode, 1888.

5 Milne-Edwards, Leçons s. 1. Physiol. t. v. p. 362. 1859. 
analogous structures described by Vanstone $^{1}$ in Melongena, that are too restricted in their area to be solely protective. I further consider that the style is composed of a reserve supply of food material, although it may also function in the manner suggested by Barrois. One of the latter's arguments against the reserve-food theory is that in its reactions the style most nearly resembles mucin; it, however, differs from it in one important respect, viz., in giving the proteid reaction with copper sulphate, and, as so many of these very different proteid compounds only differ slightly in their chemical tests, it may really be a very different body; it is, moreover, readily dissolved by the digestive juices, so that it can very easily be absorbed by the cells of the alimentary canal.

I have, moreover, tried Haseloff's starving experiments, and came to conclusions very different from those of Barrois. Having obtained 100 mussels, and, after examining a number and finding that they possessed well-developed styles, I carefully cleaned 50 and placed them in aerated filtered sea-water, the remainder being placed in a feeding tank for comparison. The starved specimens were kept in filtered water which was frequently changed, and one or two were killed every other day for a space of one month; when examining a starved mussel one of the reserve fat stock was always killed for comparison. After six days' starvation the difference in the size of the style was as much as three-quarters of an inch in two specimens of equal size, that of the starved one being of course the smaller. Examining them in this way, as time went on the difference became more and more marked, till at the end of the month many of the starved speeimens had entirely lost their styles. Thus, amongst fifteen starved mussels five showed no trace of a style, five had styles averaging ·3in., while five still retained styles of about 1 in. in length, but these were mostly very thin; whereas amongst the non-starved specimens the style averaged about 1.5in. Unfortunately, I had no time to continue the experiments and feed up the starved specimens. But I think there can be no doubt that this structure daes disappear when the animal is starved, and since it is an albuminous proteid, although differing slightly from all known food-stuffs, I see no reason to doubt its. being a reserve supply of food, which, in spite of the concentric structure, I should regard as aggregated from the digested food in the gut and not as secreted by a oiliated epithelium. ${ }^{2}$

With regard to Barrois's assertion that since the majority of marine molluses do not hibernate they do not require a reserve supply of food, I would suggest that during the winter, when many molluses migrate into deeper water, and during the breeding season, ${ }^{3}$ they

1 Vanstone, Linn. Soc. Jour. Zool. xxiv. p. 369.

2 These observations were carried out in the Laboratory of the Marine Biological Association at Plymouth, when occupying the table belonging to the British Association.

${ }^{3}$ It is interesting to note that during the process of starvation the mussels all ripened their gonads. 
may be either hard up for food or in the latter case find it more convenient to starve, and then a reserve supply of food would be very necessary. Besides, many bivalves which are more or less stationary depend for their food supply on the ocean and river currents laden with infusoria, minute algæ, etc., which certainly vary in quantity with the seasons; and all known animals when well fed lay up a store of some sort, either for the winter or for the breeding season, so that I see no reason why the Mollusca should form an exception to the rule.

In conclusion, I would again point out that the crystalline style and the sagitta may be found both in the Gastropoda and Acephala, and that the former may be developed in a special pyloric cæcum or lie freely in the gut. They both exercise a protective and probably also a triturating function, whilst the style is furthermore a reserve supply of food material.

\section{EXPLANATION OF PLATE XI.}

Anatomy of male individual of Pterocera, sp ?: the mantle cavity has been opened along the right side, and the dorsal wall with the attached organs turned over to the left side of the body.

a. anus.

a.a. anterior aorta.

au. auricle.

b.c. body cavity.

b.d. bile duct.

b.m. buccal mass.

c.d. cardiac sac of stomach.

c.g. cerebral ganglion.

c.m. columella muscle.

c.o. cardiac orifice.

cp. crop.

c.s. crystalline style.

c.t. cardiac tooth.

f. foot.

g. gill.

g.o. genital orifice.

gr. groove.

i. intestine.

k. kidney.

l. liver.

m. mantle.

m. g. mucous gland. mo. mouth.

o. operculum.

oc. eye.

os. osphradium.

p. pericardium.

pe. penis.

p.g. pedal ganglion.

pl.g. pleural ganglion.

p.o. pyloric opening.

p.t. pyloric tooth.

p.v. efferent pulmonary vein.

py. pyloric portion of stomach.

r. rectum.

r.o. renal orifice.

r.p. reno-pericardial opening.

s.g. salivary gland.

st. stomach.

t. testis.

ten. tentacle.

v. ventricle.

v.d. vas deferens.

v.g. splanchnic ganglion. 


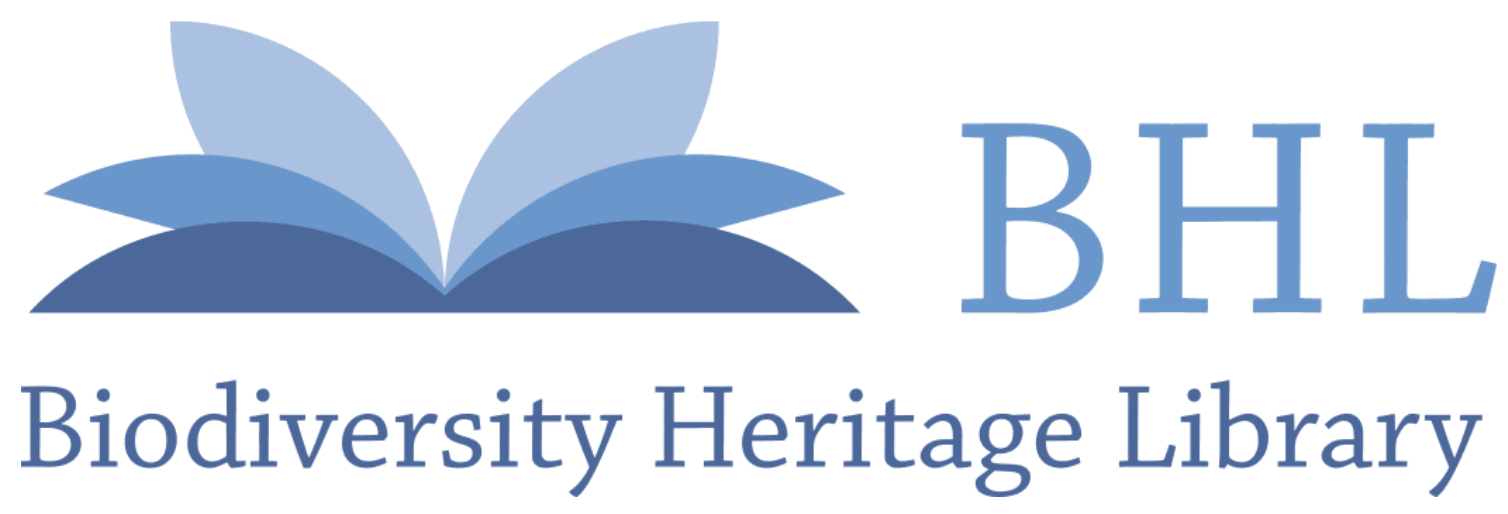

Woodward, Martin Fountain. 1894. "ON THE ANATOMY OF PTEROCERA, WITH SOME NOTES ON THE CRYSTALLINE STYLE." Proceedings of the Malacological Society of London 1, 143-150.

View This Item Online: https://www.biodiversitylibrary.org/item/52295

Permalink: https://www.biodiversitylibrary.org/partpdf/202583

\section{Holding Institution}

Smithsonian Libraries

\section{Sponsored by}

Smithsonian

\section{Copyright \& Reuse}

Copyright Status: Public domain. The BHL considers that this work is no longer under copyright protection.

This document was created from content at the Biodiversity Heritage Library, the world's largest open access digital library for biodiversity literature and archives. Visit BHL at https://www.biodiversitylibrary.org. 